\title{
Dworkin on Community and Critical Interests
}

\author{
Bernard Williams $\dagger$
}

In Liberal Community Professor Dworkin introduces a broader subject matter into ethical and political philosophy than rights-centered, or Utilitarian, liberalism has traditionally allowed. I am sympathetic to his enriching the discussion of liberalism with these philosophical materials, and I am sympathetic to many of his political conclusions. Ungratefully, I am less happy with some of the ways he uses these materials to reach his conclusions, and it is these points of concern that I shall address.

I shall stick to Dworkin's termmology, and refer to the interests under discussion as "critical" interests, but I do not find this term entirely satisfactory. ${ }^{1}$ "Critical" may imcorrectly suggest interests that are necessarily expressed in criticism or satisfied only as a result of criticism. These important long-standing interests may, indeed, come to be understood through critical thinking and may well lead to or support social criticism, but it begs some large questions to associate them necessarily with processes of criticism. ${ }^{2}$ Again, the contrast between "volitional" and "critical" interests suggests that there are two separate species of interests. But not all volitional interests will turn out really to be interests, while those that survive can bear on practical reasoning in much the same way as "critical" interests. Despite the misleading implications which Dworkin rightly poimts out, I still think that there is something to be said for the Hegehan terminology of "real" interests. "Real" arouses the suspicion of liberals, while "critical" placates them, but it is useful to recall those suspicions, particularly as a reminder that someone has to interpret these imterests.

However named, the idea seems roughly the same: something is in someone's critical interests if it makes that person's life a better life to lead. Dworkin also says: it is something that the person slould or ought to want, but in using such expressions, he does not want us to forget that critical interests are supposed to be interests, a term that is supposed to be univocal between critical and volitional interests. To say that a course of action or a way of life is in certain people's interests must be to claim

$\dagger$ Professor of Philosophy, University of California, Berkeley.

1. Dworkin, Liberal Community, 77 CAL1F. L. Rev. 479, 484 (1989).

2. Dworkin and I may well agree on this. 
something more specific than that it would be good if they adopted it; it must mean that it would be good for them if they adopted it.

Some help is offered here by the idea, stressed by Dworkin, that the person in question should acknowledge the benefits of the conduct or the life; but we need to know more about the conditions and the basis of acknowledgment. As Dworkin says, the fact that people acknowledge something as being in their interest does not mean that it really is so. This is shown, for instance, by the fact that people may be brainwashed into acknowledging the supposed interest, but the point stretches beyond brainwashing, and applies just as much to many more orthodox forms of acculturation. In this connection, Dworkin employs a familiar item, the critical assessment test, to the effect that the process leading to the acknowledgment should not leave the person in a worse position than he or she was beforehand to assess critically the two lives. ${ }^{3}$ Tests with a similar structure were proposed by Plato and by John Stuart Mill: the test for the better of two lives is supposed to lie in the preference of a person who has tried both-and, we must add, has not had his or her memory or judgment destroyed by either of them. This proviso serves to remind us of the dangers of circularity that such tests present. Simple circularity lies in identifying the capacity to judge with choosing the life preferred by the investigator. To avoid this, the test must invoke a general power of assessment. But the identification of this general power could in turn lead to dangers of begging the question at a higher level. The general capacity may be taken to include a disposition to scrutinize one's life and to seek a rationalistic justification of it-just the kind of characteristic that the opponents of liberalism see as one of its destructive products.

The doctrine of critical interests will not secure a firm foundation until the test can be applied with reference to what are incontestably general human capacities. Only this can guard it against circularity and, with that, ideological abuse. In practice, it is often not hard to detect bad (ideological) uses of the doctrine, since they are manifestly full of bad faith, appealing - as Plato at least did openly - to such things as supposed unequal distributions of intellectual powers over social classes.

But nevertheless this first step of the construction does raise what I put as the first problem (of three): How is any critical interest identified? How do we distinguish between acknowledgments that count and those that do not? What is it to be in a "good position" to judge what is in one's interests?

The second problem is raised by the identification of integration, in particular, as an element in people's critical interests. This sharpens the

3. Dworkin, supra note 1 , at 486. 
previous problem. Under what conditions are we to discover whether it is in someone's critical interest to be integrated into a community? It is certainly true that you find humans hiving in communities, and variously integrated into them; and it nay well turn out that persons outside coininunities, or who are conspicuously unintegrated, are by any test unhappy. ${ }^{4}$

But these undeniable facts do not in theinselves deliver what Dworkin wants. It is essential to his position that these facts should not lave eitler of two other explanations. One is the Hobbesian explanation (no doubt with some secondary elaboration) to the general effect that there are many things that people outside cominunities or poorly integrated into them cannot get. The other is the conservative, antiliberal explanation, that people need a dense social life formed by dominating inoral expectations. Notoriously, many of the facts are cited in support of the second explanation and many of thein are compatible witl the first. The issue is not to adjudicate liere between these interpretations, or between them and some other. The question is, what test Dworkin proposes to apply to these facts to show both that integration is an eleinent in critical interests, and that the evidence for this is not evidence for one of the two rival explanations.

Anotlier aspect of this problein, which again goes back to the general nature of critical interests, concerns the extension of the class of people in whose critical interests integration allegedly is. When Dworkin says that integration lias critical value for the lives of individual people, does he mean that it lias value for the life of each and every individual? Here Dworkin needs to locate his position, once inore, relative to the two rival explanations. The Hobbesian position finds it very hard to deliver the conclusion that integration into a society (or its own version of that) is in the interest of eacli and every person, and lience it is extravagantly open to the problem of free-riders, as Plato saw witl regard to soine of its ancient predecessors, and as Hobbes very clearly saw himself. The conservative position, on the otlier hand, seeks to show that each and every person's individual critical interest requires liin or lier to be integrated (in the strong, conservative, sense) into society. It correspondingly views those who resist integration as deviants who have fallen away from or fail to perceive their real interests. Does Dworkin lope to deliver the same breadth of conclusion, for lis own, more limited, interpretation of "integration"? If so, what will guarantee that lis tlieory of critical interests may not turn out after all to support the stronger, conservative, option?

Perliaps Dworkin should conclude that integration is usually and for the inost part in people's critical interests. The argument for integra-

4. I ignore the relevant point that very many persons in integrated circumstances are also by any test unhappy. 
tion will be grounded in a claim about the critical interests of individual people, which admits that there are exceptions. One can take a step further, however, because the output of the claim will be a set of proposals about how we should design the state, legislate, and educate peopleproposals for social practices. These proposals will be proposals for everybody, but they will be based on claims about what is usually and for the most part in people's critical interests. The fact that there is a step here raises a question that Dworkin's particular interpretation of integration, a liberal interpretation, may help to answer: While Dworkin's integrated society may or may not meet the needs of those whose critical interests do invite integration, it will certainly be a bit of relief to the minority whose critical interests do not.

But what about that interpretation? This is the third problem: it concerns Dworkin's interpretation of integration in terms of merely political participation, or at least to the exclusion of such things as sexual conformity. His argument for this involves a structural distinction between communally collective activities, such as orchestral playing, and activities not of that character, such as sex. He claims that to put stronger claims than he does on integration in the political community is to assume some misgnided anthropomorphic model of the community. ${ }^{5}$

It is unclear how this argument fits with the rest of the position. Dworkin says "those who argue that identification with community requires illiberal legislation are not arguing for a deeper level of identification than liberalism allows. They only argue for a different account of what a community's collective life really is." I think that these people will rightly feel that this goes by too fast. For how can we settle $a$ priori the question of what is relevantly meant by identification with community? How can we exclude by these merely structural arguments the possibility that the tests, whatever they may be, that identify critical interests, will show that people, usually and for the most part, have a critical interest in living in an ethically homogeneous political community? I am inclined to agree with Dworkin, though for rather more skeptical reasons, that this is unlikely to be the result, but I cannot see how a purely structural argument could show $a$ priori that such a conclusion involved a misunderstanding.

In any case, what about the structural argument itself? What about the distinction between collective and non-collective activities? It is fun-

5. Dworkin, supra note 1 , at 495 . It might be better in fact to call this, so to speak, an orchestramorphic model. The orchestra is certainly a paradigm of collective activity, but we do not have to think of it as a musical super-person, although Dworkin does seem sometimes tcmpted to do so. I suspect that to think of every orchestra as ideally a one-man band only flatters the megalomania of conductors.

6. Id. at 499 . 
damentally important here that we need (and Dworkin's argument implies) not only a distinction between collectivc acts on the one handsuch as the Berlin Philharmonic performing a Beethoven symphony, or the United States declaring war-and individual acts on the other. There has to be also a distinction between two kinds of acts by individuals: those that intentionally contribute to a collective activity and those that do not. Thus in the paradigm orchestral case, at least three things are true: (1) the activity of each person (playing the violin or the oboe in a certain way) makes sense only granted the activity of the others; (2) there is a collective activity that has its own shape and description (giving a performance of Beethoven's Fourth Symphony); (3) the collective activity provides the reason for the individual's activity. Sex, beyond pairs or small groups, satisfies, on Dworkin's description of it, neither (1) nor (2); and that is why, unlike political activity, sexual activity is not an appropriate area for the values of integration to be expressed.

It is not enough for Dworkin's account of integration simply to refer to collective acts. We have to ask what acts of individuals are relevantly related, and in what ways, to the community that is the focus of the individual's critical interests. In particular, if integration is above all to be expressed, as Dworkin proposes, by political activity, what political acts of individuals will express and contribute to their integration? Among political activities that Divorkin mentions, voting seems to fit the pattern best. ${ }^{7}$ However, there are problems here, and it is interesting that, so long as he uses this kind of structural argument to identify integration, Dworkin seems likely to be involved in the well-known paradoxes of collective action, which we might hope to have avoided by adopting a more communitarian account of liberalism. What about the activity, for instance, of voting for a candidate who one knows is going to lose? There may be ways of getting round this difficulty, but what about other political activities such as-significantly for this set of problemsprotesting? This satisfies (1), in a weak sense; but it does not seem to satisfy (2), or, if it does satisfy (2), it does not satisfy (3).

Various kinds of political participation stand at various distances from the orchestral paradigm. But if we think of integration in these formal structural terms, and if we believe that there is a critical interest in integration, and if we find political participation to be the favored form of integration, then should wc not encourage forms of political participation that come closer to the orchestral paradigm than voting does? Should we then favor such activities as standing in lines and waving the little red book in such a manner as to spell out invigorating slogans to any aerial observer? I know that this would not be to Dworkin's taste,

7. Id. at 496 . 
but if he is going to rely on the structural argument, it is unclear why he should not prefer such activities to less collective alternatives.

When we concentrate on the point that we are concerned not just with the acts of collectivities, but with different kinds of acts of individuals, it becomes clear that there is a very general difficulty that affects any structural argument such as Dworkin's. We may grant that sexual activity under some very minimal description does not satisfy (1) and (2). But there are descriptions of it under which it will satisfy those conditions-if not as strongly as the orchestra does, at least as strongly as a lot of political activity does-and those descriptions need not imply communitywide orgies. On the contrary, they may include the sorts of descriptions that would be favored by those who would like to include sexual conformity in their prescriptions for integration: for instance, engaging in sexual relations as a member of a family which itself is part of a wider ethical community. Such descriptions would of course not yield as "collective" an account of sexual activity as applies in the orchestral case; however ambitious the model, it would be unlikely to show that extramarital or otherwise irregular sex was like playing the oboe part of Beethoven's Fourth Symphony by oneself, or playing that part while the rest of the band was playing the Seventh Symphony. But conservative believers in integration could intelligibly say-indeed, they regularly do saythat it is only such a description of sexual relations, one locating them in a pattern of shared social expectations, that makes ethical sense of them.

Whether such a description is the right, or an appropriate, one is of course the question. It is much the same question, in this context, as my earlier question about what is going to be delivered by the theory of critical interests. The fact that the question recurs in this way suggests that Dworkin's structural argument comes too late not to beg it. 